\title{
PENGARUH PENAMBAHAN JAMUR TIRAM PUTIH (Pleurotus ostreatus)TERHADAP KANDUNGAN GIZI DAN SIFAT ORGANOLEPTIK BAKSO IKAN NILA (Oreochromis niloticus) WORTEL (Daucus carota L)
}

\section{[Effect of Addition White Oyster Mushrooms (Pleurotus ostreatus) to Nutrition Content and Character Organoleptik Meatball Tilapia Fish (Oreochromis niloticus) Carrot (Daucus carota L)]}

\author{
Hari Hariadi1)* dan Yuni Rahimah'2) \\ 1) Dosen Jurusan Ilmu dan Teknologi Pangan, Fakultas Pertanian, Universitas Garut, Garut \\ 2) Alumni Jurusan Ilmu Ilmu Gizi, Sekolah Tinggi Ilmu Kesehatan Imannuel, Bandung \\ *email1:raden_harie@yahoo.com
}

Diterima 5 April 2017/ Disetujui 18 April 2017

\begin{abstract}
Increased consumption of fish and vegetable expected to increasing fiber intake and protein in children. Meatballs are the favorite food of children. Tilapia is a local fish that can be processed into meatballs, as a substitute for the function of beef and to increase the consumption of fish. Carrots have advantages with other vegetables because it has a Betacarotene otherwise it is rich in potassium (potasium) and fiber, to increase fiber in meatballs added white oyster mushroom. This study aims to know the effect of the addition white oyster mushrooms to the nutrient content and character organoleptik tilapia fish carrot meatballs. The design of study is Experiment. The treatment consisted of the addition of oyster mushroom $15 \%, 17.5 \%, 20 \%$ and $22,5 \%$. The results showed that the addition of oyster mushroom $15 \%$ gives the characteristics of the best meatballs is Carbohydrates $25.56 \%$, fat $2.31 \%$, protein $11.76 \%$, crude fiber $0.71 \%$ and the character organoleptik taste, color, texture aroma regular rate the panel until to not like.
\end{abstract}

Keywords: carrot, meatballs, tilapia fish, white oyster mushroom

\begin{abstract}
ABSTRAK
Peningkatan konsumsi ikan dan sayuran diharapkan dapat meningkatkan asupan serat dan protein pada anakanak. Bakso merupakan makanan yang di gemari anak- anak. Ikan nila merupakan ikan lokal yang dapat diolah menjadi bakso, sebagai pengganti fungsi dari daging sapi dan untuk meningkatkan konsumsi ikan. Wortel memiliki kelebihan dengan sayuran lainya, karena memiliki Beta-karoten selain itu kaya akan kalium (potasium) dan serat, untuk meningkatkan serat pada bakso ditambahkan jamur tiram putih. Penelitian ini bertujuan untuk Mengetahui pengaruh penambahan jamur tiram putih terhadap kandungan zat gizi dan sifat organoleptik bakso ikan nila wortel. Desain penelitian yang digunakan adalah Eksperiment. Perlakuan terdiri dari penambahan jamur tiram putih 15\%, 17,5\%,20\% dan 22,5\%. Hasil penelitian menunjukan bahwa penambahan jamur tiram putih 15\% memberikan karakteristik bakso terbaik yaitu Karbohidrat 25,56\% , lemak $2,31 \%$, protein $11,76 \%$ serat kasar $0,71 \%$ dan sifat organoleptik rasa, warna, tekstur dan aroma panelis menilai biasa sampai agak suka.
\end{abstract}

Kata kunci: wortel, bakso, ikan nila, jamur tiram putih

\section{PENDAHULUAN}

Pangan adalah segala sesuatu yang bersumber dari sumber hayati dan air, baik yang diolah maupun tidak diolah. Pangan merupakan kebutuhan yang sangat mendasar, penganekaragaman atau diversifikasi pangan sangat beragam, mulai dari hasil pertanian, perikanan dan ternak banyak dijadikan diversifikasi pangan, yang menjadi kendala kurangnya serat, walaupun serat termasuk non gizi tetapi peran untuk kesehatan cukup penting.

Serat juga terjadi proses fermentasi dan proliferasi mikroba. Gas yang dihasilkan dari fermentasi mendorong feses ke bagian distal.
Serat yang tidak difermentasi membuat massafeses bertambah besar karena partikel serat mampu menahan air. Beberapa serat makanan dapat difermentasi oleh mikroorganisme dalam usus besar. Jenis dan jumlah serat yang dapat difermentasi sangat bervariasi. Selulosa tahan terhadap fermentasi sedangkan glukan sangat mudah difermentasi dan sempurna didegradasi dalam kolon. Umumnya serat tidak larut seperti selulosa dan hemiselulosa tahan terhadap degradasi mikrobial sehingga hanya sebagian kecil yang terfermentasi (Mustofa,2015).

Serat adalah jenis karbohidrat yang tidak terlarut, serat dalam saluran pencernaan 
manusia tidak dapat dicerna karena manusia tidak mempunyai enzim, tetapi didalam usus manusia terdapat beberapa bakteri yang dapat mencerna serat sehingga produk yang di lepas dapat diserap kedalam tubuh dan dapat digunakan sebagai sumber energy (Dep. Gizi dan Kes. Masyarakat, 2011). Konsumsi serat yang dianjurkan perhari 20-30 gram, serat dapat di peroleh dari buah-buahan dan sayuran.

Menurut Riskesdas (2013), menunjukkan bahwa proporsi rerata nasional konsumsi sayur dan buah pada penduduk di atas 10 tahun mencapai 93,5\%, ini tidak menunjukan perubahan jauh dari data sebelumnya Riskesdas 2007 sebesar 93,6\%. Dalam jurnal Gizi dan Pangan (Maret, 2014), terungkap bahwa anak Indonesia hanya mengkonsumsi $1 / 2$ porsi serat yang dianjurkan dan konsumsi serat anak kota lebih rendah dibandingkan di pedesaan.

Akibat dari kurang konsumsi serat dapat mengakibatkan sembelit, kanker kolon, wasir, penyakit cardiovascular dan obesitas (kegemukan). Penyakit infeksi yang biasanya menjadi penyebab kesakitan dan kematian mulai bergeser dan diganti oleh penyakit degenerative seperti penyakit jantung, hipertensi, kencing manis (diabetes militus), hiperkolestrol, asam urat dan penyakit degenerative lainya.

Solusi untuk dapat memenuhi asupan serat tersebut perlu adanya modifikasi makanan maka salah satunya adalah membuat bakso karena pada umumnya msyarakat Indonesia suka. Bakso ini terbuat dari sayuran yang dipakai yaitu wortel dan jamur tiram putih selain menggunakan sayuran disini juga memakai ikan nila sebagai penganti daging sapi.

Bakso adalah jenis kuliner yang berasal dari Cina, kata bakso berasal dari kata Bak So yang ada di dalam bahasa Hokkien berarti daging babi yang dicincang atau digiling. Seiring perkembangan zaman bakso sampai ke Indonesia, tetapi bakso di buat bahan dasar daging sapi karena mayoritas msyarakat Indonesia muslim (cakrakata.org/tag/sejarahbakso, 21 maret 2016). Selain daging sapi bahan-bahan pembuatan bakso ditambah tepung kanji, putih telur, bawang putih, merica dan air es.

Perkembangan selanjutnya, bahan baku bakso terbuat dari ikan hampir semua jenis ikan dapat diolah menjadi bakso ikan, dan salah satunya adalah ikan nila (Oreochromis niloticus). Ikan nila yang digunakan adalah ikan nila hitam dengan berat $500 \mathrm{~g}$, untuk ketersediaan ikan nila menurut WPI (2016) yang berasal dari Waduk Cirata mengasilkan 150 ton ikan nila hitam sedangkan di Waduk Jati luhur saat ini ketersediaan ikan nila mencapai 2.500 ton.

Kementrian Kelautan dan Perikanan (KKP) mencatat, bahwa konsumi rata-rata masyarakat Indonesia terhadap konsumsi ikan hanya sebanyak $35 \mathrm{~kg}$ per kapita/tahun. Jika dibandingkan dengan Jepang yang mencapai $60 \mathrm{~kg}$ per kapita/tahun dan Malaysia sebesar $50 \mathrm{~kg}$ per kapita/tahun. Hal itu juga membuat tingkat kecerdasan bayi lahir Indonesia hanya di level 89 dan berada dibawah rata-rata IQ negara-negara ASEAN yang memiliki IQ mencapai 91,3. Maka dari itu untuk meningkatkan konsumsi ikan dibuatlah bakso yang berbahan dasar ikan nila.

Sayuran merupakan sumber pangan yang kaya akan vitamin dan mineral yang sangat bermanfaat bagi kesehatan, perkembangan, dan pertumbuhan. Rata- rata konsumsi serat orang Indonsia adalah 10,5 gram per hari, maka perlu upaya peningkatan asupan serat salah satunya dengan menambahkan sayuran jamur tiram putih dan wortel pada bakso ikan putih. Selain peningkata asupan serat penambahan jamur tiram putih dan wortel juga dapat meningkatkan nilai gizi dan vitamin lainnya yang terdapat pada jamur tiram putih dan wortel sehingga menjadi nilai tambah pada bakso ikan nila.

Ada beberapa jenis jamur yang sering kita jumpai, salah satunya yaitu jamur tiram putih. Jamur tiram putih memiliki kelebihan di antara jamur yang lainya yaitu mengandung protein tinggi dan memiliki kandungan serat yang cukup tinggi yaitu $24,6 \%$ per 100 gram. Produksi jamur tiram putih di Indonesia pada tahun 2011 adalah $43.047 .029 \mathrm{~kg}$. Dengan jumlah penduduk sebesar 437.737.582 jiwa, maka konsumsi jamur Indonesia rata-rata adalah 0,197 kg per kapita per tahun (Sarina, 2012).

Wortel (Daucus carota L) merupakan sayuran akar yang berubah bentuk dan fungsi menjadi umbi yang menyimpan cadangan makanan. Umbi wotel ini berkulit tipis berwarna kuning kemerahan, berasa renyah, dan agak manis. Wortel terkenal dengan sumber vitamin A dan serat yang baik bagi tubuh (Indarti \& Gardjito, 2014). Ketersediaan wortel berdasarkan Susenas pada tahun 20072011 menunjukan bahwa ketersediaan wortel /kapita/tahun yaitu 7,03\%. 
Dengan ditambahkannya jamur tiram putih dan wortel akan mempengaruhi sifat organoleptik seperti warna, rasa, aroma dan tekstur. Tambahakn wortel mempercantik warna bakso menjadi warna orange dan akan mempengaruhi rasa bakso, dan tambahan jamur akan berpengaruh terhadap tekstur bakso menjadi crimi seperti urat yang terdapat pada bakso yang biasanya.

Selain mempengaruhi sifat organoleptik, kandungan gizi pada bakso ikan nila wortel jamur pasti akan berbeda dengan kandungan gizi pada bakso lainya. Dengan tambahan ikan nila, wortel dan jamur tiram putih maka dari itu ada pengecekan labolatorium meliputi karbohidrat, protein, lemak dan serat.

Berdasarkan uraian diatas maka dilakukan penelitian pengaruh penambahan jamur tiram putih pada bakso ikan nila wortel yang sesuai dengan syarat mutu, harga terjangkau oleh semua kalangan dan disukai oleh masyarakat.

\section{METODE PENELITIAN}

Metode penelitian yang digunakan adalah metode Quasi experiment (one shoot case) dan pengolahan data uji hedonik dari empat perlakukan dengan 15 Panelis tidak terlatih, mengunakan uji statistik. Perlakuan dilakukan berapa banyak jamur tiram putih yang ditambahkan pada adonan bakso ikan nila wortel, yaitu sebagai berikut:

A: Penambahan jamur tiram putih $15 \%$ dari total berat campuran daging ikan nila dan wortel

B: Penambahan jamur tiram putih $17,5 \%$ dari total berat campuran daging ikan nila dan wortel

C: Penambahan jamur tiram putih $20 \%$ dari total berat campuran daging ikan nila dan wortel

D: Penambahan jamur tiram putih $22,5 \%$ dari total berat campuran daing ikan nila dan wortel.

Pada percobaan utama maka ditambahkan jamur tiram putih sebanyak $15 \% ; 17,5 \% ; 20 \% ; 22,5 \%$ dari berat total ikan nila dan wortel untuk mengahasilkan organoleptik bakso ikan nila yang baik. Diagram alir pembuatan bakso dapat dilihat pada Gambar 1.

\section{Kriteria Pengamatan}

1. Uji Oraganoleptik

Sifat organoleptikdengan uji kesukaan atau hedonik (Soekarto,1985) terhadap warna, aroma, kenampakan keseluruhan, kerenyahan dan rasa bakso ikan nila wortel dengan penambahan jamur tiram putih dilakukan dengan cara pengisian formulir kuisioner uji organoleptik oleh panelis terdiri dari 15 orang.

2. Sifat kimia

a. Kadar protein dengan menggunakan Metode Kjeldahl (AOAC, 1990)

b. Kadar lemak dengan Metode Soxhlet (AOAC, 1990)

c. Penentuan Gula Reduksi dengan Metode Luff Schoorl (Slamet Sudarmadji, dkk. 2010)

d. Kadar serat kasar (crude fiber)

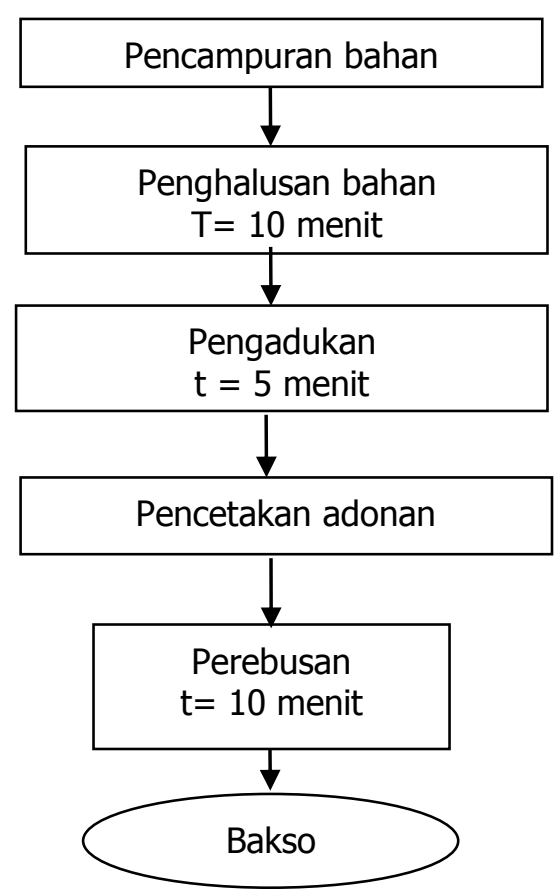

Gambar 1. Diagram Alir Pembuatan Bakso

\section{HASIL DAN PEMBAHASAN}

\section{Kesukaan Terhadap Rasa}

Berdasarkan hasil analisis statistik, penambahan wortel dan jamur tiram putih pada bakso ikan nila tidak berbeda nyata atau panelis tidak dapat membedakan terhadap kesukaan rasa. Hasil uji statistik kesukaan baso ikan nila dapat di lihat pada Tabel 1.

Berdasarkan Tabel 1 pada penambahan jamur tiram putih 15\%, 17,5\%, 20\% dan $22,5 \%$ terhadap bakso ikan nila wortel tidak berbeda nyata. Para panelis menganggap biasa dan mengarah ke agak suka terhadap bakso dengan kisaran nilai 2,15 sampai 2,16 dan imbangan $15 \%$ merupakan rasa bakso yang paling disukai karena memiliki nilai 
tertinggi yaitu 2,16. Hal tersebut menunjukan bahwa panelis dapat menerima semua bakso dengan semua perlakukan. Penambahan jamur tiram putih pada basko ikan nila wortel memberikan pengaruh tidak beda nyata terhadap kesukaan rasa pada bakso.

Tabel 1. Pengaruh Penambahan Jamur Tiram Putih Pada Bakso Ikan Nila Wortel Terhadap Kesukaan Rasa Bakso

\begin{tabular}{lcc}
\hline \multicolumn{1}{c}{ Perlakuan } & $\begin{array}{c}\text { Hasil } \\
\text { Rata- Rata }\end{array}$ & $\begin{array}{l}\text { Hasil } \\
\text { Uji }\end{array}$ \\
\hline $\begin{array}{l}\text { F1 (15\% Jamur Tiram } \\
\text { Putih) }\end{array}$ & 2,16 & $\mathrm{a}$ \\
\hline $\begin{array}{l}\text { F2 (17,5\% Jamur } \\
\text { Tiram Putih) }\end{array}$ & 2,04 & $\mathrm{a}$ \\
\hline $\begin{array}{l}\text { F3 (20\% Jamur Tiram } \\
\text { Putih) }\end{array}$ & 2,15 & $\mathrm{a}$ \\
\hline $\begin{array}{l}\text { F4 (22,5\% Jamur } \\
\text { Tiram Putih) }\end{array}$ & 2,11 & $\mathrm{a}$ \\
\hline
\end{tabular}

\section{Kesukaan Terhadap Warna}

Berdasarkan hasil analisis statistik penambahan jamur tiram putih pada bakso ikan nila wortel memberikan pengaruh nyata terhadap kesukaan warna. Hasil uji statistik kesukaan warna bakso dapat dilihat pada Tabel 2.

Tabel 2.Pengaruh Penambahan Jamur Tiram Putih pada Bakso Ikan Nila Wortel terhadap Kesukaan Warna Bakso

\begin{tabular}{lcc}
\hline \multicolumn{1}{c}{ Perlakuan } & $\begin{array}{c}\text { Hasil } \\
\text { Rata- Rata }\end{array}$ & $\begin{array}{c}\text { Hasil } \\
\text { Uji }\end{array}$ \\
\hline $\begin{array}{l}\text { F1 ( 15\% Jamur Tiram } \\
\text { Putih ) }\end{array}$ & 2,14 & $\mathrm{a}$ \\
\hline $\begin{array}{l}\text { F2 (17,5\% Jamur } \\
\text { Tiram Putih) }\end{array}$ & 2,19 & $\mathrm{ab}$ \\
\hline $\begin{array}{l}\text { F3 (20\% Jamur Tiram } \\
\text { Putih ) }\end{array}$ & 2,21 & $\mathrm{a}$ \\
\hline $\begin{array}{l}\text { F4 (22,5\% Jamur } \\
\text { Tiram Putih ) }\end{array}$ & 2,24 & $\mathrm{a}$ \\
\hline
\end{tabular}

Berdasarkan Tabel 2 warna bakso dipengaruhi oleh campuran adonan bakso. Dalam penelitian ini digunakan bahan dasar ikan nila yang berwarna putih, wortel yang berwarna orange dan jamur tiram putih yang berwarna putih. Penambahan jamur tiram putih $15 \%$ memberikan pengaruh nyata terhadap kesukaan warna bakso dibandingkan dengan penambahan jamur tiram putih $17,5 \%, 20 \%$ dan $22,5 \%$, sedangkan imbangan $20 \%$ dan $22,5 \%$ tidak berbeda nyata dibandingkan dengan penambahan jamur tiram putih $17,5 \%$.

\section{Kesukaan Terhadap Tekstur}

Berdasarkan hasil analisis statistik, penambahan jamur tiram putih pada bakso ikan nila memberikan perbedaan yang nyata terhadap kesukaan tekstur. Hasil uji statistik kesukaan tekstur dapat dilihat pada Tabel 3.

Tabel 3. Pengaruh Penambahan Jamur Tiram Putih Pada Bakso Ikan Nila Wortel Terhadap Kesukaan Tekstur Bakso

\begin{tabular}{lcc}
\hline \multicolumn{1}{c}{ Perlakuan } & $\begin{array}{c}\text { Hasil Rata- } \\
\text { Rata }\end{array}$ & $\begin{array}{c}\text { Hasil } \\
\text { Uji }\end{array}$ \\
\hline $\begin{array}{l}\text { F1 ( 15\% Jamur } \\
\text { Tiram Putih) }\end{array}$ & 2,26 & $\mathrm{a}$ \\
\hline $\begin{array}{l}\text { F2 (17,5\% Jamur } \\
\text { Tiram Putih ) }\end{array}$ & 2,16 & $\mathrm{~b}$ \\
\hline $\begin{array}{l}\text { F3 (20\% Jamur Tiram } \\
\text { Putih ) }\end{array}$ & 2,13 & $\mathrm{bc}$ \\
\hline $\begin{array}{l}\text { F4 (22,5\% Jamur } \\
\text { Tiram Putih ) }\end{array}$ & 2,06 & $\mathrm{~b}$ \\
\hline
\end{tabular}

Berdasarkan Tabel 3 penambahan jamur tiram putih $15 \%$ memberikan pengaruh yang nyata terhadap kesukaan tekstur bakso dibandingkan dengan penambahan jamur tiram putih $15,5 \%$, 20\% dan $22,5 \%$ tidak berpengaruh nyata terhadap kesukaan tektur bakso sehingga kesukaan tekstur bakso rendah dengan nilai 2,06. Panelis rata- rata menggangap tidak suka mengarah ke agak suka terhadap bakso dengan kisaran nilai yaitu 2,06 sampai 2,16 . Hal tersebut menunjukan bahwa panelis kurang menerima semua tektur bakso untuk semua perlakuan.

\section{Kesukaan terhadap Aroma}

Berdasarkan hasil statistic, penambahan jamur tiram putih pada bakso ikan nila wortel tidak memberikan pengaruh perbedaan yang nyata terhadap kesukaan aroma. Hasil uji statistic kesukaan aroma dapat di lihat pada Tabel 4.

Tabel 4. Pengaruh Penambahan Jamur Tiram Putih pada Bakso Ikan Nila Wortel terhadap Kesukaan Aroma Bakso

\begin{tabular}{lcc}
\hline \multicolumn{1}{c}{ Perlakuan } & $\begin{array}{c}\text { Hasil Rata- } \\
\text { Rata }\end{array}$ & $\begin{array}{c}\text { Hasil } \\
\text { Uji }\end{array}$ \\
\hline $\begin{array}{l}\text { F1 ( 15\% Jamur } \\
\text { Tiram Putih) }\end{array}$ & 2,16 & $\mathrm{a}$ \\
\hline $\begin{array}{l}\text { F2 (17.5\% Jamur } \\
\text { Tiram Putih) }\end{array}$ & 2,06 & $\mathrm{a}$ \\
\hline $\begin{array}{l}\text { F3 (20\% Jamur Tiram } \\
\text { Putih ) }\end{array}$ & 2,10 & $\mathrm{a}$ \\
\hline $\begin{array}{l}\text { F4 (22.5\% Jamur } \\
\text { Tiram Putih) }\end{array}$ & 2,04 & $\mathrm{a}$ \\
\hline
\end{tabular}


Penambahan jamur tiram putih pada bakso ikan nila wortel tidak memberikan pengaruh nyata terhadap kesukaan aroma pada bakso. Hal tersebut menunjukkan bahwa panelis dapat menerima semua aroma bakso untuk setiap perlakuan. Panelis rata-rata menggangap tidak suka dan mengarah ke agak suka terhadap aroma dari bakso dengan nilai antara 2,04 sampai dengan 2,16.

Hal tersebut disebabkan bau amis dari ikan nila tidak berkurang setelah di tambahkan jamur tiram putih dan wortel. Untuk 15\% jamur tiram putih panelis agak menyukai karena pada saat perebusan menggunakan rempah-rempah untuk menghilangkan bau amis dari ikan.

\section{Analisis Zat Gizi Bakso Terbaik Protein}

Protein adalah salah satu makronutrien yang sangat berperan dalam pembentukan sel jaringan dalam tubuh dan juga penghasil energi (Cakrawati, 2012). Analisis kadar protein ini dimaksudkan untuk mengetahui pengaruh penambahan jamur tiram putih dan ikan nila sebagai penganti daging sapi yang biasa di pakai dalam pembuatan bakso. Kadar protein yang di dapatkan dari hasil uji labolatorium dengan imbangan 15\% jamur tiram putih yaitu 11,76 gram, hal ini menunjukkan dengan penambahan jamur tiram putih sebesar $15 \%$ dapat memenuhi standar SNI 01- 3828- 1995 bakso ikan.

\section{Lemak}

Lemak yang dihasilkan dari uji labolatorium terhadap bakso ikan nila wortel dengan penambahan $15 \%$ jamur tiram putih yaitu sebesar 2,31 gram. Menurut SNI 013828-1995 syarat mutu bakso ikan menyatakan bahwa kadar lemak bakso ikan minimum 2,0\% hal ini menunjukan bahwa imbangan jamur tiram putih $15 \%$ memenuhi syarat mutu bakso ikan.

\section{Karbohidrat}

Karbohidrat merupakan sumber utama kalori bagi tubuh kita, di samping juga mempunyai peran penting dalam menentukan karakteristik bahan makanan, misalnya rasa, warna, tekstur dan lain- lain (Syarief dan Anies, 1998). Oleh karena itu fungsinya sangat penting bagi tubuh, maka diperlukan analisis kadar karbohidrat yang terdapat dalam bakso ikan hasil penelitian. Setelah dilakukan uji labolatorium kadar karbohidrat yang terdapat dalam bakso ikan nila yaitu 25,56 gram.

\section{Serat Kasar}

Definisi terbaru tentang serat makanan yang disampaikan oleh the American Association of Cereal Chemist (AACC,2001) merupakan bagian yang dapat dimakan dari tanaman atau karbohidrat analog yang resisten terhadap pencernaan dan absorpsi pada usus halus dengan fermentasi lengkap atau partial pada usus besar. Serat makanan tersebut meliputi pati, polisakarida, oligosakharida, lignin dan bagian tanaman lainnya. Kadar serat kasar yang terdapat pada bakso ikan yaitu 0,71 gram, dapat menyumbang sebagian asupan serat harian. Kandungan zat gizi bakso ikan nila wortel dan jamur tiram putih per 100 gramdapat dilihat pada Tabel 5.

Tabel 5. Kandungan Zat Gizi Bakso Ikan Nila Wortel dan Jamur Tiram Putih per 100 gram

\begin{tabular}{lc}
\hline \multicolumn{1}{c}{ Zat Gizi } & Jumlah (gram) \\
\hline Protein & 11,76 \\
Lemak & 2,31 \\
Karbohidrat & 25,56 \\
Serat & 0,71 \\
\hline
\end{tabular}

Setelah diketahui kandungan zat gizi protein, lemak, karbohidrat dan serat, maka, dengan mengkonsumsi bakso ikan nila wortel dan jamur tiram putih dapat menyumbang asupan zat gizi yang terdapat pada bakso ikan nila wortel dan jamur tiram putih.

\section{KESIMPULAN}

Berdasarkan hasil penelitian yang telah dilakukan, dapat disimpulkan sebagai berikut:

1. Penambahan jamur tiram putih pada ikan nila dan wortel memberikan pengaruh yang tidak berbeda nyata terhadap aroma dan rasa, tetapi berbeda nyata terhadap tekstur dan warna bakso.

2. Bakso ikan nila wortel dengan tambahan jamur tiram putih sebesar $15 \%$ memberikan hasil yang terbaik dengan karakteriktik aroma, rasa, tekstur dan rasa mendekati syarat mutu bakso ikan SNI 013828- 1995

3. Kandungan gizi bakso ikan nila wortel dan jamur tiram putih sebesar 15\% menghasilkan kandungan gizi antara lain kadar karbohidrat 25 gram, kadar lemak 2,31 gram, protein 11,27 gram dan serat $0,71 \mathrm{gram}$ telah sesuai dengan ketentuan syarat mutu bakso daging sapi berdasarkan SNI 01-3818-1995. Namun untuk serat kasar cukup rendah tetapi 
dapat menyumbang sebagian asupan serat perhari sebesar $28 \%$.

\section{DAFTAR PUSTAKA}

AACC. 2001. The Definition of Dietary Fiber. Cereal Fds. World.

Astawan M. 2004. Tetap Sehat dengan Produk Makanan Olahan. Tiga Serangkai, Solo.

Badan Standardisasi Nasional. 1995. Bakso Ikan. SNI 01-3819-1995. Badan Standardisasi Nasional, Jakarta.

Cakrakata.org/tag/sejarah-bakso [21 Maret 2016].

Cakrawati D dan Mustika NH. 2012. Bahan Pangan, Gizi dan Kesehatan. Alfabeta, Bandung

Harland BF and Oberleas D. 2001. Effects of Dietary Fiber and Phytate on the Homeostatis and Bioavailability of Minerals. CRC Handbook of Dietary Fiber in Human Nutrition, 3 Ed,G.A. Spiller, ed.,CRC Press, Bocca Raton.

Indrati Rdan Gardjito M.2014. Pendidikan Konsumsi Pangan Aspek Pengolahan Dan Kemanan Pangan Edisi 1. Kencana Predamidia Grup, Jakarta.

Khatun K, Mahtab H,Khaman PA, Sayeed MA, and Khan KA. 2007. Oyster Reduced Blood Glucose And Cholesterol In Diabetic Subject. Mymensingh Medj 16(1): 94-9.

Nor I. 2015. Row Food Diet, Jalan Menuju Hidup Sehat. Lierindo, Yogyakarta.

Perlindungan AK. 2000.Pengaruh Konsentrasi Urea Dan TSP Didalam Air Rendaman Baglong Alang- Alng Tehadap Jamur Tiram Putih (Pleurotusos Treatus).
ISSN online: $2443-3446$

Prosiding Seminar Hasil Penelitian Dosen UNIR. Pekanbaru.

Piliang WG dan Djojosoebagio SAH. 2002. Fisiologi Nutrisi. Vol. 1. Edisi ke -4. IPB Press, Bogor.

Prosky L and De Viers JW. 1992. Controlling Dietary Fiber in Food Product. Van Nostrand Reinhold, New York.

Rukmana R. 1995. Bertanam Wortel. Penerbit Kaninus, Yogyakarta

Setyaningsih Dwi, Apriyanto A dan Puspita M. 2010. Analisi Sensori untuk Industri Pangan dan Agro Bogor: IPB Press

Soekarto TS. 1985. Penilaian Organoleptik. Bahasa Karya Aksara, Jakarta

Sudarmadji S, Haryono B dan Suhardi. 2010. Prosedur Analisa Untuk Bahan Makanan dan Pertanian Edisi 3. LIBERTY, Yogyakarta

Sumarmi.2006. Botani dan Peninjauan Gizi Nilai Jamur Tiram Putih. J Inovasi Pertanian 4(2): 124-130.

Sunarjono. 1984. Kunci Bercocok Tanam Sayur-sayuran Penting di Indonesia. Sinar Baru, Bandung.

Suprapti ML. 2005. Tepung Tapioka Pembuatan dan Pemanfaatannya. Kaninus, Yogyakarta.

Syafrina O. 2015. Tentukan Makanan Berdasarkan Usia. Efata Publising, ISBN: 978-602-1348-31-4.

Syarif R dan Irawati A. 1998. Pengetahuan Bahan untuk Industri Pertanian. Mediyatama sarana Perkasa, Jakarta.

Wibowo S. 2009. Membuat Bakso Sehat dan Enak. Penebar Swadaya, Jakarta.

Winarno FG. 2002. Kimia Pangan dan Gizi. Gramedia Pustaka Utama, Jakarta. 